\title{
Metabolic Syndrome in psoriasis: a hospital based cross-sectional study in Central India
}

\author{
Singh Bhati S. ${ }^{1}$, Shah A. ${ }^{2 *}$, Chaudhary S. ${ }^{3}$, Kumar S. ${ }^{4}$, Tomar A. ${ }^{5}$, Jain S. ${ }^{6}$ \\ DOI: https://doi.org/10.17511/ijmrr.2019.i04.10
}

${ }^{1}$ Surendra Singh Bhati, Assistant Professor, Index Medical College Hospital \& Research Center, Indore, Madhya Pradesh, India.

2* Akhil Shah, Associate Professor, Amaltas Institute of Medical Sciences, Dewas, Madhya Pradesh, India.

3 Subhash Chaudhary, PG Resident, Index Medical College Hospital \& Research Center, Indore, Madhya Pradesh, India.

${ }^{4}$ Saket Kumar, PG Resident, Index Medical College Hospital \& Research Center, Indore, Madhya Pradesh, India.

5 Anushtha Tomar, PG Resident, Index Medical College Hospital \& Research Center, Indore, Madhya Pradesh, India.

6 Shubhang Jain, PG Resident, Index Medical College Hospital \& Research Center, Indore, Madhya Pradesh, India.

Background: Psoriasis is a chronic immune-mediated inflammatory disorder, reported to be associated with obesity, dyslipidaemia and diabetes via common immunological mechanisms. All of these components ultimately increase the risk of metabolic syndrome and cardiovascular morbidities. Aims and Objectives: To assess the association of Metabolic Syndrome (MS) and its components in patients suffering from psoriasis. To study the relationship between the duration and severity of psoriasis and MS. Materials and Methods: A hospital based cross-sectional study was conducted involving 100 adult patients with psoriasis and 100 controls. All participants were evaluated forpsoriasis and the components of MS. Psoriasis was categorized as mild, moderate and severe based on Psoriasis Area and Severity Index (PASI) ( $<7,8-12$ and $>12$, respectively). In all patients and controls, body mass index was calculated, blood pressure and waist circumference were measured and fasting blood sugar and lipid profile were estimated. Results: In the present study, a higher prevalence of $\mathrm{MS}$ in Psoriasis patients than in controls ( $38 \% \mathrm{v} / \mathrm{s} 23 \%$ ) was observed. Psoriatic patients had higher prevalence of hypertension ( $36 \% \mathrm{v} / \mathrm{s} 14 \%$ ). It can be concluded that association of MS and psoriasis is independent of the type, duration and severity of psoriasis. Conclusion: The present study suggests that subjects with psoriasis present a greater risk of MS and should trigger a higher clinical suspicion for their co-existence. Psoriasis is a systemic disease with significant morbidity and mortality. This study emphasizes the critical need for providers to screen psoriasis patients for early diagnosis and treatment of associated MS.

Keywords: Psoriasis, Metabolic Syndrome, Hypertension, Obesity, Diabetes

Corresponding Author

Akhil Shah, Associate Professor, Amaltas Institute of Medical Sciences, Dewas, Madhya Pradesh, India. Email: akhil108@yahoo.com
How to Cite this Article

Bhati SS, Shah A, Chaudhary S, Kumar S, Tomar A, Jain S. Metabolic Syndrome in psoriasis: a hospital based cross-sectional study in Central India. Int J Med Res Rev. 2019;7(4):315-323.

Available From

https://ijmrr.medresearch.in/index.php/ijmrr/article/ view/1075
To Browse

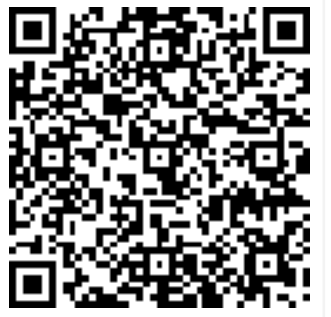

Manuscript Received 2019-07-10

Conflict of Interest No

Review Round 1
2019-07-20
Funding
Nil

Review Round 2 2019-07-26

Ethical Approval Yes
Review Round 3

Accepted 2019-07-31

Plagiarism X-checker $8 \%$
Note

(c) 2019 by Surendra Singh Bhati, Akhil Shah, Subhash Chaudhary, Saket Kumar, Anushtha Tomar, Shubhang Jain and Published by Siddharth Health Research and Social Welfare Society. This is an Open Access article licensed under a Creative Commons Attribution 4.0 International License https://creativecommons.org/licenses/by/4.0/ unported [CC BY 4.0] 


\section{Introduction}

Psoriasis is a common, chronic, immune-mediated inflammatory and proliferative condition of the skin characterized by red, scaly, sharply demarcated, indurated plaques, present particularly over extensor surfaces and scalp[1]. The prevalence varies from $0.1 \%$ to $3 \%$ across geographical regions of the world, greatest in northern colder climates [2] [3]. In India, it varies from $0.84 \%$ to $5.6 \%$ in different studies [4]. The disease is characterized by $\mathrm{T}$ cell-mediated hyperproliferation of keratinocytes and inflammatory processes based on a complex genetic background [5-7]. Psoriasis has been reported to be associated with metabolic disorders including obesity, dyslipidaemia and diabetes [8$11]$. MS is a clustering of several medical conditions such as central obesity, arterial hypertension, glucose intolerance, high serum triglycerides and low high-density lipoprotein (HDL) levels (4).

It has been recognized as a pro-inflammatory, prothrombotic state associated with elevated levels of C-reactive protein (CRP), interleukin (IL)-6, and plasminogen activator inhibitor (PAI)-1 [12]. This yumellitus. The prevalence of MS varies according to the studied population as it suffers influence of genetics, aging, sedentary behaviour and diet. [13]. Metabolic syndrome (MS) and psoriasis share certain common immunological mechanisms. The exact mechanism for this interaction remains uncertain but the link between them may be the effects of pro-inflammatory cytokines and adipocytes on glucose regulation, lipid status, and endothelial function. The present study is undertaken to evaluate more about the epidemiological and clinical profile of psoriasis and to assess its association with MS.

\section{Materials and Methods}

Study duration: Across sectional study was conducted over a period of two years betweenNov 2015 and Nov 2017 at a Tertiary Care Hospital in Central India.

Inclusion criteria: All clinically diagnosed cases of psoriasis with age more than 18 years, attending Dermatologyoutpatient department were included.

Exclusion criteria: Pregnant women, patient on current treatment and those who received cyclosporine, acitretin, psoralens and methotrexate at least one month before enrolment were excluded.
Data collection: After obtaining the informed consent, detailed history was taken including duration of the disease, alcohol intake, smoking, anyconcomitant illness, intake of medications in the past for psoriasis or other illnesses. Clinical examination was conducted, which included the anthropometric measurements and blood pressure. Fasting Plasma Glucose (FPG) and Fasting Lipid Profile (FLP) were done in all patients. Similar examination and investigations were done in controls as well Under current guidelines, revised in 2005 by the National Heart, Lung, and Blood Institute (NHLBI) and the American Heart Association (AHA), MS was diagnosed when a patient has at least 3 of the following 5 conditions:

- FPG $\geq 100 \mathrm{mg} / \mathrm{dL}$ (or receiving drug therapy for hyperglycaemia)

- Blood Pressure (BP) $\geq 130 / 85 \mathrm{~mm} \mathrm{Hg}$ (or receiving drug therapy for hypertension)

- Triglycerides (TG) $\geq 150 \mathrm{mg} / \mathrm{dL}$ (or receiving drug therapy for hypertriglyceridemia)

- High Density Lipoprotein $(\mathrm{HDL})<40 \mathrm{mg} / \mathrm{dL}$ in men or $<50 \mathrm{mg} / \mathrm{dL}$ in women (or receiving drug therapy for reduced HDL)

- Waist circumference $\geq 102 \mathrm{~cm}$ (40 in) in men or $\geq 88 \mathrm{~cm}$ (35 in) in women

(If Asian American, $\geq 90 \mathrm{~cm}$ (35 in) in men or $\geq 80$ $\mathrm{cm}$ (32 in) in women).

\section{Scoring systems used}

- PASI: Extent of involvement was assessed using Psoriasis Area and Severity Index (PASI), a composite score from 0 to 72 that evaluates the erythema, induration, and scaling of the lesions in four body areas (head, trunk, arms and legs).

Mild psoriasis classified as a PASI between 0 - 7, moderate between 8 - 12andsevere $>12$.

- BMI:The Body Mass Index (BMI) was determined by weight and height calculations using the following equation:

BMI = weight in $\mathrm{kg} /$ square of height in meters

According to Indian guidelines, a BMI from 23 to 24.9 is overweight, a BMI greater than or equal to 25 is moderate obesity, and a BMI greater than or equal to 30 is severe obesity.

Data analysis: Frequencies, percentages, mean and standard deviation (SD) values of variables in case and control group were calculated. Categorical (Qualitative) variables (percentages and 
Frequencies) were analysed using Pearson's Chi square test.

Continuous variables were compared using unpaired t-test (normal distribution of data) and MannWhitney $U$ test (non-normal distribution of data). Shapiro-Wilks test was applied to evaluate whether data follows normal distribution. Binomial logistics regression analysis was done to calculate odds ratio to determine association of Psoriasis with FPG, BP, TG, HDL and waist circum-ference and MS in comparison with controls.

$P$ values $<0.05$ were considered statistically significant.

Data analysis was done using Statistical Package for Social Sciences (SPSS) v.21.

\section{Results}

The total of 100 patients were enrolled in the study, out of which 67 were men and 33 were women. The mean age for cases and controls were 41.60 years and 42.08 years respectively. There was no significant difference between cases and controls for age and sex distribution. (Table 1)

Table -1: Descriptive statistics of cases and controls.

\begin{tabular}{|c|c|c|c|c|}
\hline Chara & $\mid \begin{array}{c}\text { Case } \\
(n=100)\end{array}$ & $\begin{array}{l}\text { Control } \\
(n=100)\end{array}$ & $\begin{array}{c}\text { Statistical } \\
\text { Test }\end{array}$ & P Value \\
\hline $\begin{array}{l}\text { Age (years) } \\
\text { (Mean } \pm \text { SD) }\end{array}$ & $\mid \begin{array}{l}41.60 \pm 13 \\
.70\end{array}$ & $\begin{array}{l}42.08 \pm 13 . \\
97\end{array}$ & $\begin{array}{l}t \text {-test value }= \\
0.245\end{array}$ & $\begin{array}{l}0.806(>0.05) \text { Not } \\
\text { Significant }\end{array}$ \\
\hline \multicolumn{5}{|l|}{ Sex } \\
\hline Male $(n)$ & 67 & 69 & \multirow{2}{*}{$\begin{array}{l}\text { Chi-square } \\
\text { test }=0.092\end{array}$} & \multirow{2}{*}{$\begin{array}{l}0.762(>0.05) \text { Not } \\
\text { Significant }\end{array}$} \\
\hline Female (n) & 33 & 31 & & \\
\hline \multicolumn{5}{|l|}{ Smoking } \\
\hline Yes(n) & 15 & 23 & \multirow{2}{*}{$\begin{array}{l}\text { Chi-square } \\
\text { test }=2.079\end{array}$} & \multirow{2}{*}{$\begin{array}{l}0.149(>0.05) \text { Not } \\
\text { Significant }\end{array}$} \\
\hline No (n) & 85 & 77 & & \\
\hline \multicolumn{5}{|l|}{ Alcohol } \\
\hline Yes(n) & 06 & 13 & \multirow{2}{*}{$\begin{array}{l}\text { Chi-square } \\
\text { test }=2.079\end{array}$} & \multirow{2}{*}{$\begin{array}{l}0.149(>0.05) \text { Not } \\
\text { Significant }\end{array}$} \\
\hline No(n) & 94 & 87 & & \\
\hline $\begin{array}{l}\text { BMI }(\mathrm{Kg} / \mathrm{m} 2) \\
(\text { Mean } \pm \mathrm{SD})\end{array}$ & $\begin{array}{l}22.93 \pm 4 . \\
70\end{array}$ & $\begin{array}{l}21.92 \pm 4.4 \\
4\end{array}$ & $\begin{array}{l}t \text {-test value }= \\
1.565\end{array}$ & $\begin{array}{l}0.119(>0.05) \text { Not } \\
\text { Significant }\end{array}$ \\
\hline
\end{tabular}

[No significant difference between cases and controls for age, sex distribution, smoking status, alcohol status and BMI.]

Smoking, alcohol consumption and BMI: There was no significant difference between cases and controls for smoking status $(P=0.149)$, alcohol status $(P=0.149)$ and BMI $(P=0.119)$. (Table 1$)$
MS in cases and controls- The prevalence of MS was significantly higher in cases than controls (38/100 vs 23/100: $\mathrm{P}=0.022$ ) (Table 2)

Hypertension- Hypertension was found to be significantly more common in cases than controls (36/100 vs 14/100: $\mathrm{P}=0.000$ ) (Table 2)

FPG, TG, HDL, Waist Circumference- There was no significant difference between cases and controls forFPG $(P=0.874)$, TG $(P=0.885)$, HDL $(P=0.479)$ and Waist circumference $(P=0.883)$. (Table 2$)$

Table-2: The distribution of clinical and laboratory findings in cases and controls

\begin{tabular}{|c|c|c|c|c|}
\hline Findings & $\begin{array}{c}\text { Case } \\
(n=100)\end{array}$ & $\begin{array}{l}\text { Control } \\
(n=100)\end{array}$ & $\begin{array}{c}\text { Odds } \\
\text { Ratio(95\% CI) }\end{array}$ & P Value \\
\hline \multicolumn{5}{|c|}{ Fasting blood glucose $(\geq 100 \mathrm{mg} / \mathrm{dl})$} \\
\hline Yes $(n)$ & 27 & 28 & \multirow[t]{2}{*}{$0.95(0.51-1.77)$} & \multirow{2}{*}{$\begin{array}{l}0.874(>0.05) \text { Not } \\
\text { significant }\end{array}$} \\
\hline No $(n)$ & 73 & 72 & & \\
\hline \multicolumn{5}{|c|}{ Blood pressure $\geq 130 / 85 \mathrm{~mm} \mathrm{Hg}$} \\
\hline Yes $(n)$ & 36 & 14 & \multirow{2}{*}{$\begin{array}{l}3.45(1.72- \\
6.94)\end{array}$} & \multirow{2}{*}{$\begin{array}{l}0.000(<0.05) \\
\text { significant }\end{array}$} \\
\hline No $(n)$ & 64 & 86 & & \\
\hline \multicolumn{5}{|c|}{ Triglycerides $\geq 150 \mathrm{mg} / \mathrm{dl}$} \\
\hline Yes $(n)$ & 41 & 40 & \multirow{2}{*}{$\begin{array}{l}1.04(0.59- \\
1.83)\end{array}$} & \multirow{2}{*}{$\begin{array}{l}0.885(>0.05) \text { Not } \\
\text { significant }\end{array}$} \\
\hline No $(n)$ & 59 & 60 & & \\
\hline \multicolumn{5}{|c|}{$\mathrm{HDL}<40 \mathrm{mg} / \mathrm{dl}$ in men or $<50 \mathrm{mg} / \mathrm{dl}$ in women } \\
\hline Yes $(n)$ & 51 & 46 & \multirow{2}{*}{$\begin{array}{l}1.22(0.70- \\
2.13)\end{array}$} & \multirow{2}{*}{$\begin{array}{l}0.479(>0.05) \text { Not } \\
\text { Significant }\end{array}$} \\
\hline No $(n)$ & 49 & 54 & & \\
\hline \multicolumn{5}{|c|}{ Waist circumference $\geq 90 \mathrm{~cm}$ ( $35 \mathrm{in}$ ) in men or $\geq 80 \mathrm{~cm}$ ( $32 \mathrm{in}$ ) in women } \\
\hline Yes $(n)$ & 36 & 37 & \multirow{2}{*}{$\begin{array}{l}0.96(0.54- \\
1.70)\end{array}$} & \multirow{2}{*}{$\begin{array}{l}0.883(>0.05) \text { Not } \\
\text { Significant }\end{array}$} \\
\hline No $(\mathrm{n})$ & 64 & 63 & & \\
\hline \multicolumn{5}{|c|}{ Metabolic syndrome } \\
\hline $\begin{array}{l}\text { Present } \\
(\mathrm{n})\end{array}$ & 38 & 23 & \multirow[t]{2}{*}{$\begin{array}{l}2.05(1.11- \\
3.80)\end{array}$} & \multirow[t]{2}{*}{$\begin{array}{l}0.022(<0.05) \\
\text { Significant }\end{array}$} \\
\hline $\begin{array}{l}\text { Absent } \\
\text { (n) }\end{array}$ & 62 & 77 & & \\
\hline
\end{tabular}

Table-3: Association between different types of psoriasis and $\mathbf{m s}$

\begin{tabular}{|l|l|l|l|}
\hline \multirow{2}{*}{ Types of psoriasis } & \multicolumn{2}{|c|}{ Metabolic syndrome } & \multirow{2}{*}{ Total $\mathrm{n}(\%)$} \\
\cline { 2 - 3 } & Present $\mathrm{n}(\%)$ & Absent $\mathrm{n}(\%)$ & \\
\hline Chronic plaque & $28(37.3)$ & $47(62.7)$ & $75(100.0)$ \\
\hline Erythrodermic & $2(100.0)$ & $00(0.0)$ & $2(100.0)$ \\
\hline Guttate & $00(0.0)$ & $03(100.0)$ & $3(100.0)$ \\
\hline Palmoplantar & $06(50.0)$ & $06(50.0)$ & $12(100.0)$ \\
\hline Scalp & $02(25.0)$ & $06(75.0)$ & $08(100.0)$ \\
\hline Total & $38(38)$ & $62(62)$ & $100(100.0)$ \\
\hline $\begin{array}{l}\text { Chi-square test value }=6.423, \mathrm{df}=4, \mathrm{P} \text { value }=0.170(>0.05), \text { Not } \\
\text { significant }\end{array}$
\end{tabular}

[Presence or absence of MS was not associated with type of psoriasis] 
Table-4: Association between duration of psoriasis and $\mathbf{m s}$

\begin{tabular}{|l|l|l|l|l|l|}
\hline \multirow{2}{*}{$\begin{array}{l}\text { puration of } \\
\text { psoriasis }\end{array}$} & \multicolumn{2}{|c|}{ Metabolic syndrome } & Mann-Whitney & P value \\
\cline { 2 - 4 } & Present & Absent ( & Over all & U statistics & \\
Years & $7.70 \pm 9$ & $n=62)$ & $(n=100)$ & & \\
$($ Mean \pm SD $)$ & 54 & .18 & $9.13 \pm 7.6$ & 1080.500 & $0.487(>0.05)$ \\
\hline
\end{tabular}

[Presence or absence of MS was not associated with duration of psoriasis]

Table -5: Association between different types of psoriasis and obesity (bmi scores)

\begin{tabular}{|c|c|c|c|c|c|c|}
\hline \multirow{2}{*}{$\begin{array}{c}\text { Types of } \\
\text { psoriasis }\end{array}$} & \multicolumn{5}{|c|}{ Obesity (BMI scores) } & \multirow{2}{*}{$\begin{array}{l}\text { Total } \\
\text { n (\%) }\end{array}$} \\
\hline & $\begin{array}{l}\text { Underweig } \\
\text { ht n (\%) }\end{array}$ & $\begin{array}{l}\text { Normal } \\
n(\%)\end{array}$ & $\begin{array}{l}\text { Over } \\
\text { weight n } \\
(\%)\end{array}$ & $\begin{array}{l}\text { Moderate } \\
\text { obesity n } \\
(\%)\end{array}$ & $\begin{array}{l}\text { Severe } \\
\text { obesity n } \\
(\%)\end{array}$ & \\
\hline $\begin{array}{l}\text { Chronic } \\
\text { plaque }\end{array}$ & $14(18.7)$ & $\begin{array}{l}29 \\
(38.7)\end{array}$ & $09(12.0)$ & $17(22.7)$ & $06(8.0)$ & $\begin{array}{l}75 \\
(100.0)\end{array}$ \\
\hline $\begin{array}{l}\text { Erythroder } \\
\text { mic }\end{array}$ & $00(0.0)$ & $\left.\begin{array}{l}01 \\
(50.0)\end{array}\right)$ & $01(50.0)$ & $00(0.0)$ & $00(0.0)$ & $\begin{array}{l}2 \\
(100.0)\end{array}$ \\
\hline Guttate & $00(0.0)$ & $\left.\begin{array}{l}02 \\
(66.7)\end{array}\right)$ & $00(0.0)$ & $01(33.3)$ & $00(0.0)$ & $\begin{array}{l}3 \\
(100.0)\end{array}$ \\
\hline $\begin{array}{l}\text { Palmoplant } \\
\text { ar }\end{array}$ & $00(0.0)$ & $\left.\begin{array}{l}06 \\
(50.0)\end{array}\right)$ & 02 (16.7) & $03(25.0)$ & $01(08.3)$ & $\left|\begin{array}{l}12 \\
(100.0)\end{array}\right|$ \\
\hline Scalp & $00(0.0)$ & $\begin{array}{l}03 \\
(37.5)\end{array}$ & $02(25.0)$ & $03(37.5)$ & $00(0.0)$ & $\left|\begin{array}{l}08 \\
(100.0)\end{array}\right|$ \\
\hline Total & $14(14.0)$ & $\begin{array}{l}41 \\
(41.0)\end{array}$ & $14(14.0)$ & $24(24.0)$ & $07(7.0)$ & $\left.\begin{array}{l}100 \\
(100.0)\end{array}\right)$ \\
\hline \multicolumn{7}{|c|}{$\begin{array}{l}\text { Chi-square test value }=11.091, \mathrm{df}=16, \mathrm{P} \text { value }=0.804(>0.05), \text { Not } \\
\text { significant }\end{array}$} \\
\hline
\end{tabular}

[Obesity was not associated with type of psoriasis]

Table-6: Association between severity of psoriasis (according to PASI) and MS

\begin{tabular}{|l|l|l|l|}
\hline \multirow{2}{*}{ Severity of psoriasis } & \multicolumn{2}{|c|}{ Metabolic syndrome } & \multirow{2}{*}{ Total n (\%) } \\
\cline { 2 - 3 } & Present n (\%) & Absent n (\%) & \\
\hline Mild & $24(40.7)$ & $35(59.3)$ & $59(100.0)$ \\
\hline Moderate & $04(25.0)$ & $12(75.0)$ & $16(100.0)$ \\
\hline Severe & $10(40.0)$ & $15(60.0)$ & $25(100.0)$ \\
\hline Total & $38(38.0)$ & $62(62.0)$ & $100(100.0)$ \\
\hline $\begin{array}{l}\text { Chi-square test value }=1.370, \mathrm{df}=2, \mathrm{P} \text { value }=0.504(>0.05), \text { Not } \\
\text { significant }\end{array}$
\end{tabular}

[Presence or absence of MS was not associated with severity of psoriasis]

Type of psoriasis- Presence or absence of MS was not found to be associated with type of psoriasis $(P=0.170)$. (Table 3)

MS and duration of psoriasis- Presence or absence of MS was not associated with duration ofpsoriasis $(P=0.487)$. (Table 4 )
Obesity and psoriasis- No correlation was found between type of psoriasis and obesity $(P=0.804)$ (Table 5)

PASI- According to PASI score out of 100 cases $59 / 100$ had mild psoriasis (PASI $\leq 7$ ), 16/100 had moderate psoriasis (PASI $=8$ to 12 ), and 25/100 had severe psoriasis (PASI >12).

Severity of Psoriasis and MS- No correlation was found between severity of psoriasis and MS $(P=0.504)$. (Table 6)

\section{Discussion}

A direct correlation between severity of psoriasis and the prevalence of obesity, dyslipidemia and hyperhomocysteinaemia has been reported in psoriatic patients $[14,15]$ suggesting that skin changes (inflammation) caused by psoriasis have a direct role in determining these risk factors. Psoriasis has also been found to be associated with relevant cardiovascular risk factors [16].

The concomitant occurrence of dyslipidemia,glucose intolerance, obesity and hypertension constitute the MS, which has been similarly defined by the WHO, the NCEP ATP III and the EGIR $[17,18]$.

Mallbriset al. in 2006 discussed the metabolic disorders in patients with psoriasis and psoriatic arthritis [19]. In the same year, Sommer et al. showed that MS was more prevalent in psoriasis patients [10]. Since then, there have been many studies from various parts of the world showing the same findings $[20,21]$.

In this study it was found that prevalence of MS is present in $38 \%$ of psoriatic patient as compared to $23 \%$ of controls which shows MS is significantly higher in psoriatic patients compared with controls $(P=0.022)$. Similar results were found in Indian studies done by Madanagobalaneet al. (44\% cases vs $30 \%$ controls, $\mathrm{P}=0.025$ ) [22], Nisa \& Quazi [23], Khunger $\mathrm{N}$ et al [24] \& Prathapet al [25].

Studies by Gisondiet al $(37.8 \%$ cases vs $23.3 \%$ controls had hypertriglyceridemia, $\mathrm{P}=0.001$ and $18 \%$ cases vs $21.2 \%$ controls had low HDL, $P=0.2$ ) [20], Neimannet al [11], Takahashi $H$ et al [21], Madanagobalaneet al. [22], Nisa \& Quazi [23], Khunger $\mathrm{N}$ et al [24] demonstrated that a dyslipidemic profile consisting of either increased levels of TG or decreased levels of HDL cholesterol is exhibited by patients with psoriasis. 
In contrast to these studies our findings TG level $\geq$ 150 (41\% cases vs $40 \%$ controls $\mathrm{OR}=1.04$, $\mathrm{P}=0.885$ ) \& HDL level $<40$ for males $\&<50$ for females ( $51 \%$ cases vs $46 \%$ controls $\mathrm{OR}=1.22$ $\mathrm{P}=0.479$ ) does not support association of dyslipidemia with psoriasis. The present study supports the findings of Ilkin $Z$ et al (45.2\% cases vs $39.3 \%$ controls had hypertriglyceridemia, $\mathrm{P}=0.340$ and $43.5 \%$ cases vs $32.9 \%$ controls had low HDL, $\mathrm{P}=0.082)$, Prathapet al [25], Mehta NN et al [27].

The present study observed no correlation between risk of DM II/high FPG $>100 \mathrm{mg} \%$ ( $27 \%$ cases vs $28 \%$ controls $\mathrm{OR}=0.95, \mathrm{P}=0.874$ ) with psoriasis which was consistent with the results of Gisondiet al (19.2\% cases vs $20.9 \%$ controls, $P=0.6)[20]$, Khunger $\mathrm{N}$ et al [24], Prathapet al. [25]. On the other hand, Qureshi, A. et al [9], Neimannet al [11], Takahashi $\mathrm{H}$ et al[21], Madanagobalaneet al. [22], Nisa and Quazi [23], Ilkin Z et al [26], Mehta NN et al [27], Ghiasi, M.et al [28], Azfar RS et al [29] reported a significantly higher prevalence of impaired FPG levels in psoriatic patient as compared to controls.

Although obesity is reported more frequent among psoriatic patients, BMI and waist circumference were not found significantly higher in psoriatic patients [abdominal obesity $\geq 90 \mathrm{cmin}$ females and $\geq 100 \mathrm{~cm}$ in females ( $36 \%$ cases vs $37 \%$ controls, $\mathrm{OR}=0.96, \mathrm{P}=0.883)$ ], these results were consistent with the findings of Ilkin $Z$ et al $(73 \%$ cases vs $83.6 \%$ controls)[26].

In contrast to our findings, studiesdone by Gisondiet al (57.1\% cases vs $47.6 \%$ controls, $\mathrm{P}=0.01$ ) [20], Madana-gobalaneetal. [22], Nisa and Quazi [23], Khunger $\mathrm{N}$ et al[24] \& Prathapet al [25] reported significantly higher prevalence of increased waist circumference in psoriatic patients. MS is a strong predictor of cardiovascular diseases, diabetes and stroke and significantly increases the risk of cardiovascular mortality compared with the individual factors $[30,31]$. In Western Europe the prevalence of $\mathrm{MS}$ is similar to the U.S.A. ranging from $15 \%$ to $35 \%$ [32] in developing countries the prevalence of MS is lower, but recent epidemiological studies are registering a rapid increase [33].

The link between psoriasis and hypertension may be related to the increased levels of angiotensinconverting enzyme, endothelin-1 (ET-1) and rennin in patients with psoriasis.
44,45 It was also observed that higher prevalence hypertension $\geq 130 / 85 \mathrm{~mm}$ of $\mathrm{Hg}$ (36/100 vs $14 / 100 \mathrm{OR}=3.45, \mathrm{P}=0.000$ ) which is in accordance with studies done by Qureshi A. et al[9], Sommer et al[10], Neimannet al [11], Takahashi $H$ et al [21], Madanago-balaneet al. [22], Nisa \& Quazi, Khunger $\mathrm{N}$ et al[24], Ilkin Z et al [26], Mehta NN et al [27], Ghiasi $M$ et al [28]. In contrast Gisondiet al (40.8\% cases vs $39.5 \%$ controls $P=0.7$ ) [20], Prathapet al [25] found no correlation between psoriasis \& hypertension. There are conflicting reports regarding the duration of disease and severity of psoriasis with MS. It was observed that no association was present between severity of psoriasis \& MS. Similar observations were seen by Gisondiet al (no difference in prevalence of MS in patients with PASI score lower or higher than 10 , $30.1 \%$ vs $29.4 \%$ respectively $p=0.9$ )[20], Takahashi $\mathrm{H}$ et al [21], Madanagobalaneet al [22] Niza \& Qazi [23].

In contrast Sommer et al [10], Prathapet al [25], Langan SMet al [36] observed that MS is significantly more prevalent in patients who have moderate and severe psoriasis. The present study observed no association between presence or absence of MS with duration of psoriasis which is consistent with the findings of Madanago-balaneet al [22]. Contrary to this, study by Gisondiet al (longer duration of disease in cases having MS $18.1 \pm 16.1$ years as compared to cases not having MS 13.3 \pm 12.0 years) [20], Niza \& Qazi [23], Prathapet al [25] has shown a positive association between longer duration of psoriasis and MS. It was also observed that presence or absence of Metabolic Syndrome was not associated with type of psoriasis (Chi-square test value $=6.423, \mathrm{df}=4, \mathrm{P}$ value $=$ 0.170 (>0.05), Not significant).

\section{Conclusion}

In the present study, an association between psoriasis and the presence of MS independently of psoriasis severity, alcohol \& smoking habit have been confirmed. The hypothesis that obesity can favour psoriasis needs to be addressed in prospective studies. It can be suggested that all patients with psoriasis should be encouraged to correct aggressively their modifiable cardiovascular risk factors, in particular, metabolic syndrome. It is also suggested that patients with psoriasis should be assessed for the concomitant presence of diseases, such as ischemic heart disease, hypertension, DM and obesity. 
The present findings also have important clinical implications. First, a diagnosis of psoriasis should trigger a high clinical suspicion and investigation for a potential coexistence of the metabolic syndrome. If present, the syndrome needs to be recognized as a potential risk factor for $\mathrm{CV}$ disease and more life threatening than psoriasis given the serious associated complications[37].

\section{Limitation}

This is the first study on the association of MS in Central India patients with psoriasis. Although the sample may not represent the whole country but it gives an idea of co-morbidities of psoriasis.

The present study has several limitations. As it is a cross-sectional study which does not allow the direction of the association to be ascertained. Secondly, the study is conducted in Central India and the population analyzed may not be representative of the entire country.

\section{What does this study add to existing knowledge?}

Some studies have been previously done to speculate the association between Psoriasis and MS. In the present study, there was also an assessmentof the association of Psoriasis with individual components of MS, which gives a finer ideaof the association of both these conditions.

\section{Author's contributions}

Dr. Surendra Singh Bhati: Principal investigator, Data collection, Data analysis

Dr. Akhil Shah: Co-investigator, Data collection

Dr. Subhash Chaudhary: Data Collection

Dr. Saket Kumar: Data collection

Dr. Anushtha Tomar: Data collection

Dr. Shubhang Jain: Data collection

\section{Reference}

01. Griffiths CEM, Camp RDR, Barker JNWN. Psoriasis, In- Rook's Textbook of Dermatology, Burns T, Breathnach S, Cox N, Griffiths C editors, Seventh edition. Blackwell Science, Oxford. 2005;35(1)35-69.

[Crossref]
02. Baker H. Psoriasis a review. Dermatol. $1975 ; 150$ (1)16-25.

[Crossref]

03. Linden KG, Weinstein GD. Psoriasis- current perspectives with an emphasis on treatment. Am J Med. 1999;107(6)595-605.

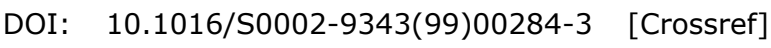

04. Bedi TR. Clinical profile of psoriasis in North Indi a. Indian J Dermatol Venereol. 1995;61(4)202-

5. [Crossref]

05. Barker JNWN. The pathophysiology of psoriasis. Lancet. 1993;338(8761)227-30.

doi: 10.1016/0140-6736(91)90357-U [Crossref]

06. Christopher E, Mrowietz U. Psoriasis, InFreeberg IM, Eisen AZ, Wolff K, Austen KF, Goldsmith LA, Katz SI, editors, Fitzpatrick's Dermatology in General Medicine- 6th Edn. New York- McGraw-Hill. 2003;1;407-427.

[Crossref]

07. Griffiths TW, Griffiths CEM, Voorhees JJ. Immuno-pathogenesis and immunotherapy of psoriasis. Dermatol Clinics. 1995;13(4)739-49.

[Crossref]

08. Reynoso-von Drateln C, Martı'nez-Abundis $E$, Balca'zar-Mun oz BR, Bustos- Saldaña R, Gonza'lez-Ortiz M. Lipid profile, insulin secretion, and insulin sensitivity in psoriasis. J Am Acad Dermatol. 2003;48(6)882-885.

doi: $10.1067 / \mathrm{mjd} .2003 .446$ [Crossref]

09. Qureshi AA, Choi HK, Setty AR, Curhan GC. Psoriasis and the risk of diabetes and hypertension- a prospective study of US female nurses. Arch Dermatol. 2009;145(4)379-382.

doi: 10.1001/archdermatol.2009.48 [Crossref]

10. Sommer DM, Jenisch S, Suchan M, Christophers $E$, Weichenthal $M$. Increased prevalence of the metabolic syndrome in patients with moderate to severe psoriasis. Arch Dermatol Res. $2006 ; 298(7) 321-8$.

doi: $\quad 10.1007 / s 00403-006-0703-z \quad$ [Crossref]

11. Neimann $A L$, Shin $D B$, Wang $X$, Margolis DJ, Troxel AB, Gelfand JM. Prevalence of cardiovascular risk factors in patients with psoriasis. J Am Acad Dermatol. 2006;55(5)829-35.

doi: $10.1016 /$ j.jaad.2006.08.040 [Crossref] 
12. Ridker PM, Buring JE, Cook NR, Rifai N. Creactive protein, the metabolic syndrome, and risk of incident cardiovascular events- an 8-year follow-up of 14719 initially healthy American women. Circulation. 2003;107(3)391-7.

doi: 10.1161/01.cir.0000055014.62083.05 [Crossref]

13. Gennuso KP, Gangnon RE, Thraen-Borowski KM, Colbert LH. Dose-response relationships between sedentary behaviour and the metabolic syndrome and its components. Diabetologia. 2015;58(3)485-92.

doi: $\quad 10.1007 / s 00125-014-3453-z \quad$ [Crossref]

14. Malerba $M$, Gisondi $P$, Radaeli A, Sala $R$, Calzavara Pinton PG, Girolomoni G. Plasma homocysteine and folate levels in patients with chronic plaque psoriasis. $\mathrm{Br} \mathrm{J}$ Dermatol. 2006;155(6)1165-9.

doi: $10.1111 /$ j.1365-2133.2006.07503.x [Crossref]

15. Naldi L, Chatenoud L, Linder D, Belloni Fortina $A$, Peserico A, Virgili $A R$, et al. Cigarette smoking, body mass index, and stressful life events as risk factors for psoriasis- results from an Italian case-control study. J Invest Dermatol. 2005; 125(1)61-7.

doi: $10.1111 /$ j.0022-202X.2005.23681.x [Crossref]

16. Kimhi O, Caspi D, Bornstein NM, Maharshak N, Gur A, Arbel $Y$, et al. Prevalence and risk factors of atherosclerosis in patients with psoriatic arth ritis. Semin Arthritis Rheum. 2007;36(4)203-9. doi: 10.1016/j.semarthrit.2006.09.001 [Crossref]

17. National Institute of Health. Third report of the National Cholesterol Education Program Export Panel on Detection, Evaluation, and Treatment of High Blood Cholesterol in Adults (Adult Treatment Panel III), Executive Summary. NIH publ no 01-3670. Bethesda.

MD- National Institute of Health, National Heart, Lung and Blood Institute. 2001 [Crossref]

18. Alberti KG, Zimmet PZ. Definition, diagnosis and classification of diabetes mellitus and its com plications, Part 1- diagnosis and classification of diabetes mellitus provisional report of a WHO consultation. Diabet Med. 1998;15(7)539-53.

doi: $10.1002 /(S I C I) 1096-9136(199807) 15: 7<539:$ :

AID-DIA668>3.0.CO;2-S [Crossref]
19. Mallbris L, Ritchlin CT, Ståhle M. Metabolic disorders in patients with psoriasis and psoriatic arthritis. Curr Rheumatol Rep. 2006;8(5)35563.

[Crossref]

20. Gisondi P, Tessari G, Conti A, Piaserico S, Schianchi $S$, Peserico $A$, et al. Prevalence of metabolic syndrome in patients with psoriasis- a hospital-based case-control study. $\mathrm{Br}$ J Dermatol. 2007;157(1)68-73.

doi: $10.1111 /$ j.1365-2133.2007.07986.x [Crossref]

21. Takahashi H, Takahashi I, Honma M, IshidaYamamoto A, Iizuka $\mathrm{H}$. Prevalence of metabolic syndrome in Japanese psoriasis patients. J Dermatol Sci. 2010;57(2)143-4.

doi: 10.1016/j.jdermsci.2009.11.002 [Crossref]

22. Madanagobalane S, Anandan S. Prevalence of metabolic syndrome in South Indian patients with psoriasis vulgaris and the relation between disease severity and metabolic syndrome- A hospital based case control study. Indian J Dermatol. 2012;57(5)353-357.

doi: $10.4103 / 0019-5154.100474$ [Crossref]

23. Nisa N, Qazi MA. Prevalence of metabolic syndrome in patients with psoriasis. Indian J Dermatol Venereol Leprol. 2010;76(6)662-5. doi: 10.4103/0378-6323.72462 [Crossref]

24. Khunger N, Gupta D, Ramesh V. Is psoriasis a new cutaneous marker for metabolic syndrome? - A study in Indian patients. Indian J Dermatol. $2013 ; 58(4) 313$. doi: $10.4103 / 0019-5154.113958$ [Crossref]

25. Prathap P, Asokan N, Manjula VD. A case control study to determine the association of psoriasis with metabolic syndrome in a tertiary care centre. IJSRP. 2014;4(5)1-4.

[Crossref]

26. Zindancı I, Albayrak O, Kavala M, Kocaturk E, Can B, Sudogan S, Koç M. Prevalence of metabolic syndrome in patients with psoriasis. Scientific World J. 2012.

doi: 10.1100/2012/312463 [Crossref] 
27. Mehta NN, Azfar RS, Shin DB, Neimann AL, Troxel AB, Gelfand JM. Patients with severe psoriasis are at increased risk of cardiovascular mortality- cohort study using the General Practice Research Database. Eur Heart J. 2010;31(8)1000-6.

doi: 10.1093/eurheartj/ehp567 [Crossref]

28. Ghiasi $M$, Nouri $M$, Abbasi A, Hatami $P$, Abbasi MA, Nourijelyani K. Psoriasis and increased prevalence of hypertension and diabetes mellitus. Indian journal of dermatology. $2011 ; 56(5) 533$.

doi: $10.4103 / 0019-5154.87149$ [Crossref]

29. Azfar RS, Seminara NM, Shin DB, Troxel AB, Margolis DJ, Gelfand JM. Increased risk of diabetes mellitus and likelihood of receiving diabetes mellitus treatment in patients with psoriasis. Arch Dermatol. 2012;148(9)9951000.

doi: 10.1001/archdermatol.2012.1401 [Crossref]

30. Wannamethee SG, Shaper AG, Lennon L, Morris RW. Metabolic syndrome vs Framingham Risk Score for prediction of coronary heart disease, stroke, and type 2 diabetes mellitus. Arch Intern Med. 2005;165(22)2644-50.

DOI: 10.1001/archinte.165.22.2644 [Crossref]

31. Meigs JB, Wilson PW, Fox CS, Vasan RS, Nathan DM, Sullivan LM, et al. Body mass index, metabolic syndrome, and risk of type 2 diabetes or cardiovascular disease. J Clin Endocrinol Metab. 2006;91(8)2906-12.

doi: $10.1210 /$ jc.2006-0594 [Crossref]
32. Cameron AJ, Shaw JE, Zimmet PZ. The metabolic syndrome: prevalence in worldwide populations. Endocrinol Metab Clin North Am. 2004;33(2)351-75.

DOI: $10.1016 /$ j.ecl.2004.03.005 [Crossref]

33. Gu D, Reynolds K, Wu X, Chen J, Duan X, Reynolds RF, Whelton PK, et al. Prevalence of the metabolic syndrome and overweight among adults in China. Lancet. 2005;365(9468) 1398405.

DOI: $10.1016 / \mathrm{S} 0140-6736(05) 66375-1 \quad$ [Crossref]

34. Ena P, Madeddu P, Glorioso N, Cerimele D, Rappelli A. High prevalence of cardiovascular diseases and enhanced activity of the reninangiotensin system in psoriatic patients. Acta Cardiol. 1985;40(2)199-205.

[Crossref]

35. Das UN. Is angiotensin-II an endogenous proinflammatory molecule?. Med Sci Monit. 2005;11(5)RA155-162.

[Crossref]

36. Langan SM, Seminara NM, Shin DB, Troxel AB, Kimmel SE, Mehta NN, et al. Prevalence of metabolic syndrome in patients with psoriasis- a population-based study in the United Kingdom. J Invest Dermatol. 2012;132(3 Pt 1)556-62.

doi: $10.1038 /$ jid.2011.365 [Crossref]

37. Gelfand JM, Neimann AL, Shin DB, Wang $X$, Margolis DJ, Troxel AB. Risk of myocardial infarction in patients with psoriasis. JAMA. 2006;296(14)1735-41.

DOI: $\quad 10.1001 /$ jama.296.14.1735 [Crossref] 